\title{
ON SOME POINTS IN THE MORPHOLOGY AND BIOLOGY OF A NEW SPECIES OF HAWORTHIA.
}

\author{
By S. Schönland, Ph.D., F.R.S.S.Af.
}

(Plate XXVI.)

(Read June 16, 1909.)

Haworthia truncata, Schönl., n. sp.

Radices carnosi elongati. Caulis brevissimus carnosus. Folia 2-5 stricte disticha $2-3 \mathrm{~cm}$. longa medio circ. $17 \mathrm{~mm}$. lata carnosa applanata ovatodeltoidea truncata suberecta leviter incuivula, apice faciem suboblongam medio constrictam tuberculis minutis rugosam exhibientia, supra apicem versus convexa longitudinaliter canaliculata tuberculis minutis rugosa infra vaginantia concava lævia ad margines tenuiter denticulatc-ciliata, subtus convexa medio longitudinaliter leviter canaliculata superne tuberculis minutis rugosa. Pedunculus erectus gracilis simplex filiformis, e basi vacue bracteatus incl. racemo laxo $20-25 \mathrm{~cm}$. altus. Bractei ovato-acuminati membranacei 4-5 mm. longi pedicellis subæquantes. Perigonium c. $10 \mathrm{~mm}$. longum albidum obscure striatum tubo subventricoso segmentis bilabiatis. Stylus ovario triplo brevior. Capsula oblonga, triquetra, $8 \mathrm{~mm}$. longa, semina $3 \mathrm{~mm}$. longa irregulariter subtriquetra.

On a farm, 7 miles from Oudtshoorn, Miss L. Britten, B.A., April, 1909.

This new species is very interesting from several points of view, on some of which I beg to offer a few remarks. It is evidently allied to the species which have been placed under the sections Venosa, Berger, and Retusa, Haw.**

In the first place, it is the only species of Haworthia hitherto known with bifarious arrangement of leaves. However, in the allied genus Aloe there are several species which show this arrangement, although the majority of species, when adult, have multifarious leaves, and in another genus, Gasteria, it is quite common. There is nothing to indicate whether

* See A. Berger, "Liliaceæ-Asphodeloideæ-Aloineæ," in Engler's " Pflanzenreich," Heft. 33, 1908, pp. 97, 99. 
such species with distichous leaves represent ancient types, or whether they show simply a reversal to a more primitive type.

From the appearance of the specimens as they reached me, it seemed that the stem and a portion of the leaves are underground, so that only a very small portion of the upper rugose part of the leaves and the inflorescence are exposed,* and Miss Britten later informed me that this is certainly the case.

It does not require much imagination to come to the conclusion that the exposed parts resemble, to a large extent, pebbles of stone, and most likely the plant derives a considerable amount of protection from its partly hypogean habit. I would, therefore, suggest that it has to be classed with the so-called " mimicry" plants to which Burchell, $\uparrow$ Marloth, + and Thiselton-Dyer $\S$ have called attention. It would thus be the first monocotyledonous plant belonging to this category, but I believe several other species of Haworthia are similarly protected. H. truncata is not the only species of its genus which buries itself to a certain extent underground. Several species of the sections Venosa and Retusa do this also to a considerable extent. In our species the roots showed decided transverse wrinkles, and it is therefore safe to conclude that they are contractile, and draw the plant gradually into the ground as the stem elongates at the top, while its older portions die off. In the stemless species of Aloe the stem is also constantly pulled into the ground by adventitious roots, $\|$ though this may not show itself in specimens cultivated in pots. Thus in our species the stem and the greater portion of the leaves remain buried, while only the rugose portion of the leaves protrudes aboveground. The underground parts of the leaves continue, however, to act as assimilating organs, and the median channels on the back and front of the leaves no doubt help to facilitate an interchange of gases, while arrangements against excessive transpiration are ample. Stomata, which, as in other members of the genus, are sunk below the surface, are found scattered chiefly in the lower portion of the leaves. They decrease towards the apex, and are quite absent on the flat top. Longitudinal sections show that, while the assimilating tissue is arranged along the side-walls, the apex and centre are quite free from chlorophyll. There is a strong cuticle covering the whole of the leaf. It is especially thick in the upper third. The small tubercles in the upper flat portion are several-celled and impede, to a certain extent, the light entering the leaf, as I could make

* Similar largely underground foliage leaves are found in Mesembrianthemum ( $\$$ Spharoidea) and in Bulbine mesembrianthemoides.

† " Travels in the Interior of Southern Africa," i., p. 210.

† Trans. S. Afr. Phil. Soc., xv., 1904, p. 97; xvi., 1905, p. 165 ; xviii., 1907, p. 281.

$\S$ Annals of Botany, xx., p. 124.

II A. Berger, l.c., p. 4. 
out by means of a few simple experiments. The assimilating tissue is represented by several layers of spongy parenchyma, in which at intervals, arranged in two rows, longitudinal sacs of rather long raphides of oxalate of lime can be seen. Adjoining the assimilating tissue are the vascular bundles in which sclerenchymatous elements are absent. The greater part of the interior is occupied by a thin-walled very transparent waterstoring tissue. The whole structure resembles to such a remarkable degree Berger's figure* of a longitudinal section of $H$. retusa that at first sight I thought it represented our species. Both in this species and in ours very little light can enter the leaf except through the chlorophyll-free top, its "window." Similar arrangements, though somewhat modified, are found in many other species of Haworthia, H. retusa, and H. truncata being extreme cases. Now, in the description to his figure, Berger adduces $H$. retusa as an example of a structure in which the light is made use of to the greatest extent, while in the same figure he represents two other species covered with tubercles, which protect these species against too much light. It seems extraordinary that species of the same genus, provided they are living under similar conditions, should show such remarkable differences, some species being protected against excessive light, while others have special arrangements to make use of it. However, the apparent contradiction seems to be capable of an easy explanation. It is more and more recognised that plants cannot make use of intense sunlight; in fact, their chloroplasts require protection against excessively intense light (compare, e.g., Schimper, "Plant Geography," Engl. Ed. p. 58). We have very little exact knowledge on this point yet, but the researches of Wiesner (see, e.g., J. Wiesner, "Der faktische Lichtgenus der Pflanzen, Ber. d. d. bot. Ges., 1894, Generalversammlungsheft,” p. 78), have shown that in the majority of plants the amount of light actually enjoyed is very much less than the amount available. Schimper points to the fact that the vegetation of very sunny spots is never pure green, and exhibits an admixture of yellow and brown tints due to the products of decomposition of chlorophyll, $\uparrow$ but on the whole he does not think that land plants generally require very elaborate protection against excessive light, and yet an enormous number of our plants show almost at the first glance that only a small fraction of the sunlight which is at their disposal can be really utilised by them. Hairs, waxy covering, mutual shading of parts, succulency, and a host of other contrivances are to be found which must considerably reduce the light reaching the assimilating tissues.

* Berger, l.c., p. 12, fig. 7, D.

† Marloth, on p. 218 of his recently published magnificent work "Das Kapland, insonderheit das Reich der Kapflora, das Waldgebiet und die Karroo pflanzengeographisch dargestellts" (Jena, 1908), has incidentally emphasised this point with reference to many Karroo bushes. "There is no trace of green, even the scanty small leaves have the same nasty colour as the wood. Brown is the colour of the Karroo." 
These contrivances are usually also calculated to reduce transpiration very considerably, and their function in this direction is undoubtedly of vital importance to the plant, but at the same time the fact that they reduce the light has hitherto, as a rule, not received that attention which it deserves. A large number of our South African plants, although apparently exposed to the fierce rays of the sun, are really physiological shade-plants.*

Now $H$. truncata has actually retired into the shade by burying itself to a large extent underground, and as the basal part of the leaf still acts as an assimilating organ, some provision is necessary for the light to reach it at all, and the light can only reach it through the "window" which is at the top. It does not require any learned calculations to show that the amount of light entering through such a window cannot be very great, and, moreover, the window-pane is not quite clear. I abstain from making any remarks on other species of Haworthia with similar "windows," as I have not observed them amongst their natural surroundings, $\dagger$ and have no precise information as to how they grow under those conditions, nor can I say anything about the peculiar Bulbine mesembrianthemoides which I have not seen alive.

* O. V. Derbyshire, in his " Observations on Mamillaria elongata" (Annals of Botany, xviii., p. 375), concludes that the papillæ on some species of Mesembrianthemum, and the terminal bristles on others, serve also the purpose of diminishing the light that reaches the assimilating tissues. I hope to be able to refer to his conclusions more in detail before long, as I am conducting a series of experiments which are calculated to throw light on them. In the meantime I should like to state my opinion that they seem to me to require clear experimental proof before they can be accepted in their entirety.

† The whole argument of Berger's that these plants have arrangements which secure an improved supply of light, and which do not serve as a protection against intense light, appears to me, however, quite wrong without a similar explanation as I have given for H. truncata.

\section{DESCRIPTION OF PLATE.}

FIG.

Haworthia tRuncata, Schönl., n. sp.

1. Whole plant (natural size).

2. Dorsal view of leaf with tops of roots and base of peduncle (natural size).

3. Median longitudinal section of leaves and stem. The thick black lines in the leaves indicate the extent of the assimilating tissue (natural size).

4. Two stamens and portion of the corolla (about $3 / 1$ ).

5. Gynæcium, \&c. (about 3/1).

6. Young capsule, with corolla still attached (natural size).

\%. Ripe open capsule (natural size). 


\section{$2 \mathrm{BHL}$ Biodiversity Heritage Library}

Schönland, S . 1910. "ON SOME POINTS IN THE MORPHOLOGY AND BIOLOGY OF A NEW SPECIES OF HOWORTHIA." Transactions of the Royal Society of South Africa 1, 391-394. https://doi.org/10.1080/00359191009520049.

View This Item Online: https://www.biodiversitylibrary.org/item/181696

DOI: https://doi.org/10.1080/00359191009520049

Permalink: https://www.biodiversitylibrary.org/partpdf/175470

\section{Holding Institution}

Smithsonian Libraries

\section{Sponsored by}

Biodiversity Heritage Library

\section{Copyright \& Reuse}

Copyright Status: Not in copyright. The BHL knows of no copyright restrictions on this item.

This document was created from content at the Biodiversity Heritage Library, the world's largest open access digital library for biodiversity literature and archives. Visit BHL at https://www.biodiversitylibrary.org. 